\title{
Effect of the Treatment with Dexamethasone, for 10 and 15 Days, on the Fertility in Induced Rats to Polycystic Ovaries, by Constant Illumination
}

\author{
Efecto del Tratamiento con Dexametasona, por 10 y 15 Días, sobre la Fertilidad \\ en Ratas Inducidas a Ovarios Poliquísticos por la Iluminación Constante \\ Eleonora de Figueiredo Moraes; Valéria Wanderley Teixeira; Álvaro Aguiar Coelho Teixeira; \\ Welma Emídio da Silva; Ana Paula Castor Batista \& Ana Janaína Jeanine Martins de Lemos
}

MORAES, E. F.; WANDERLEY-TEIXEIRA, V. ; TEIXEIRA, A. A. C.; SILVA, W. E.; BATISTA, A. P. C. \& LEMOS, A. J. J. M. Effect of the treatment with dexamethasone, for 10 and 15 days, on the fertility in induced rats to polycystic ovaries, by constant illumination. Int. J. Morphol., 26(3):659-663, 2008.

SUMMARY: The present study had the objective of obtaining information about fertility in rats treated with dexamethasone for 10 and 15 days consecutively, to polycystic ovaries, induced by constant illumination. It was used 40 albino rats (Rattus norvegicus albinus), aged 90 days, form the lineage Wistar, which were split, randomly, in four groups, each constituted of 10 animals, namely: Group I - rats kept in a clear/dark cycle for 12/12 hours, and after 100 days submitted to fertility evaluation (control); Group II - rats kept under constant illumination during 100 days and then submitted to fertility evaluation; Group III - rats kept under constant illumination during 100 days, then treated with dexamethasone for 10 days and submitted to fertility evaluation; Group IV - rats kept under constant illumination during 100 days, then treated with dexamethasone for 15 days and submitted to fertility evaluation. The results showed that the number of implanted sites was 38(G1), 37(G2), 32(G3) and 06(G4). The reduction in group IV was due to the high mortality during the experiment, probably because of the prolonged treatment with dexamethasone. These sites presented similar histological aspects. The macroscopic analysis of the neonates haven't shown any indication of malformation. Also, abortion haven't been observed. The treatment with dexamethasone for 10 days in rats does not affect the fertility and the development of the lungs, liver and kidneys of neonates, while the administration during 15 days leads to a high maternal mortality.

KEY WORDS: Fertility; Polycystic ovaries; Dexamethasone; Rats.

\section{INTRODUCTION}

The polycystic ovaries syndrome is considered the most common way of Infertility by anovulation and menstrual irregularities that assault women in the menacme period (Melo et al., 2000).

The literature relates that several factors can lead to the interruption of the estral cycle and, therefore, induce the permanent estrous in rats. Among these factors constant illumination is highlighted, sound, steroid hormone use in recent newborn, exposition to ionizing radiation and pinealectomy (Wrenn et al., 1969; Aihara et al., 1988; Pardi, 1992; Patriarca, 1995; Santos et al., 1995).

It is known that constant illumination inhibits melatonin synthesis, through pineal gland, which is produced in the dark environment phase, so it exists a daylight harmony in the liberation of melatonin (Buckle, 1983; Neves, 2000). Benson \& Orts (1972) and Fritz \& Speroff (1982) report that the higher the luminous stimulus, the smaller the synthesis, because the exposition to light inhibits the sympathetic fibers that form the nerves around the pineal and that in this condition there is an increase of circulating estrogens. According to Prata Lima et al. (1995) when such arts are exposed to a continuous luminous stimulus, they enter a permanent estrous estate and develop polycystic ovaries.

Some clinic treatments have been employed to combat this pathology, among them we can highlight the 
MORAES, E. F.; WANDERLEY-TEIXEIRA, V.; TEIXEIRA, A. A. C.; SILVA, W. E.; BATISTA, A. P. C. \& LEMOS, A. J. J. M. Effect of the treatment with dexamethasone, for 10 and 15 days, on the fertility in induced rats to polycystic ovaries, by constant illumination. Int. J. Morphol., 26(3):659-663, 2008.

administration of glucocorticoids (Melo et al.; TeránDávila \& Teppa-Garrán, 2001; Huang \& Shirley 2001). The glucocorticoids, among them the dexamethasone, inhibits the number of induced answers by the estrogens, even blocking the mitotic activity (Stewart et al., 1983).

It is known, though, that the prolonged use of glucocorticoids, especially when administered by systemic via are limited by important adverse effects. These effects include adrenal suppression, bones, conjunctive tissue and, in children, a decrease in the speed of growth (Pedesen \& Obyrne 1997). But Caldas \& Schrank (2001) recommend the progressive reduction (weaning) of the glucocorticoids in prolonged treatments in order to minimize the adverse effects.

We should mention, yet, that several authors report that the excessive exposition to glucocorticoids during pregnancy can produce undesirable effects in the formation of the placenta and in several organs of the offspring (Bigsby \& Young, 1993; Canlon et al., 2003; Scavo et al., 2003). However, there is no report of one evaluation of fertility after a prolonged clinical treatment with dexamethasone. This way, the present study had the objective of obtaining information about the fertility in rats treated with dexamethasone.

\section{MATERIAL AND METHOD}

We used 40 albino rats (Rattus norvegicus albinus) from the Wistar lineage, aged 90 days, virgins, weighing around $200 \mathrm{~g}$, from the Biotery of the Department of Morphology and Animal Physiology from the Federal Rural University of Pernambuco. After a period of adaptation, vaginal smears were collected for determining the estral cycle. The female that presented 3 regular estral cycles were divided, randomly, in four groups. Group Irats kept in a clear/dark cycle for 12/12 hours, and after 100 days submitted to fertility evaluation (control); Group II - rats kept under constant illumination during 100 days and then submitted to fertility evaluation; Group III - rats kept under constant illumination during 100 days, then treated with dexamethasone for 10 days and submitted to fertility evaluation; Group IV - rats kept under constant illumination during 100 days, then treated with dexamethasone for 15 days and submitted to fertility evaluation. For the constant luminous stimulus it was used a box of wood nearly $0,5 \mathrm{~cm}^{3}$, well dimensioned and ventilated, containing two light bulbs (Phillips, daylight model, $20 \mathrm{~W}$ each) that supplied around 400 Lux in the region occupied by the animals. These light bulbs were kept on during all the experiment.

After 100 days of experiment, vaginal smears were done in group I, for confirming the cycle, and in groups II, III and IV for the permanent estrous verification. After the treatment with dexamethasone, it was done the cycle estral analysis of all experimental groups, the female that were cycling were coupled in the proportion of one male for two females. For the treatment it was used the dexamethasone dissodium phosphate (Decadron $®)$, in a concentration of $4 \mathrm{mg} / \mathrm{ml}$, where it was administered by intraperitonial injections in a dosage of $0,2 \mathrm{ml} /$ day/animal, according to the methodology described by Cruz et al. (1996), for the 5 first days in group III and in the 8 first days in group IV. After these periods it was proceeded a daily reduction in the dosage of $0,04 \mathrm{ml}$ for group III and $0,03 \mathrm{ml}$ for group IV, so the last day of treatment of each group the dosage was 0 (zero). The weaning procedure (progressive reduction of administration) is recommended by Caldas \& Schrank with the intention of minimizing the adverse effects of the drug.

Five females from each group were coupled and euthanized in the sixth day after the confirmation of the coupling. For doing so, the animals were anesthetized with ketamine hydrochloride $(80 \mathrm{mg} / \mathrm{Kg})$ and xylazin $(6 \mathrm{mg} /$ $\mathrm{Kg}$ ), intramuscularly. Then an opening was made until de abdominal cavity from pubis until the brim of the spare ribs, proceeding after the disjunction of the pubic symphysis, to facilitate the complete removal of the uterus. After, the uterine horn containing implantation sites were then removed and drowned immediately in Bouin liquid, being kept there for 48 hours. Next, the animals were euthanized, deepening the anesthesia until the lethal dosage. At the end of the fixation, the uterine horns were placed, one by one, on a Petri plate and taken to a magnifying glass for the counting of the implantation sites, using as reference the dilated areas presented by them. After these procedures, the uterine horns were transversally and longitudinally cleavaged, obtaining the fragments, which were processed for inclusion in paraffin and dyed by Hematoxilin-eosin.

The other 5 females from each group were coupled and accompanied for a period of 21 days, that is, until the birth of the young animals, which were analyzed macroscopically and the euthanized for the histological analysis of the lungs liver and kidneys. The macroscopic analysis was done through the observation of any visible malformation and alterations in weight a size of the young animals. For the histological analysis of the young animals it was used the same technique describe for the sites of implantation. 
MORAES, E. F.; WANDERLEY-TEIXEIRA, V.; TEIXEIRA, A. A. C.; SILVA, W. E.; BATISTA, A. P. C. \& LEMOS, A. J. J. M. Effect of the treatment with dexamethasone, for 10 and 15 days, on the fertility in induced rats to polycystic ovaries, by constant illumination. Int. J. Morphol., 26(3):659-663, 2008.

\section{RESULTS}

It was evidenced the points of implantation in the rats of all experimental groups, which were in number of 38 (Group I), 37 (Group II), 32 (Group III) and 06 (Group IV). However we must mention that 9 rats from group IV died during the experiment. The histological analysis of the implantation sites demonstrated that the same presented similar morphological aspects. These sites were totally adhered to the uterus wall, presenting very lean gaps. The trophoblasts presented different development stages with myotic activity, but it was observed a few polyploid cytotrophoblasts (Fig. 1).

The macroscopic analysis of the neonates of Group III didn't show any evidence of malformation in the head, members, thorax and abdomen. Also it was not observed abortions. The histological analysis showed that the treatment
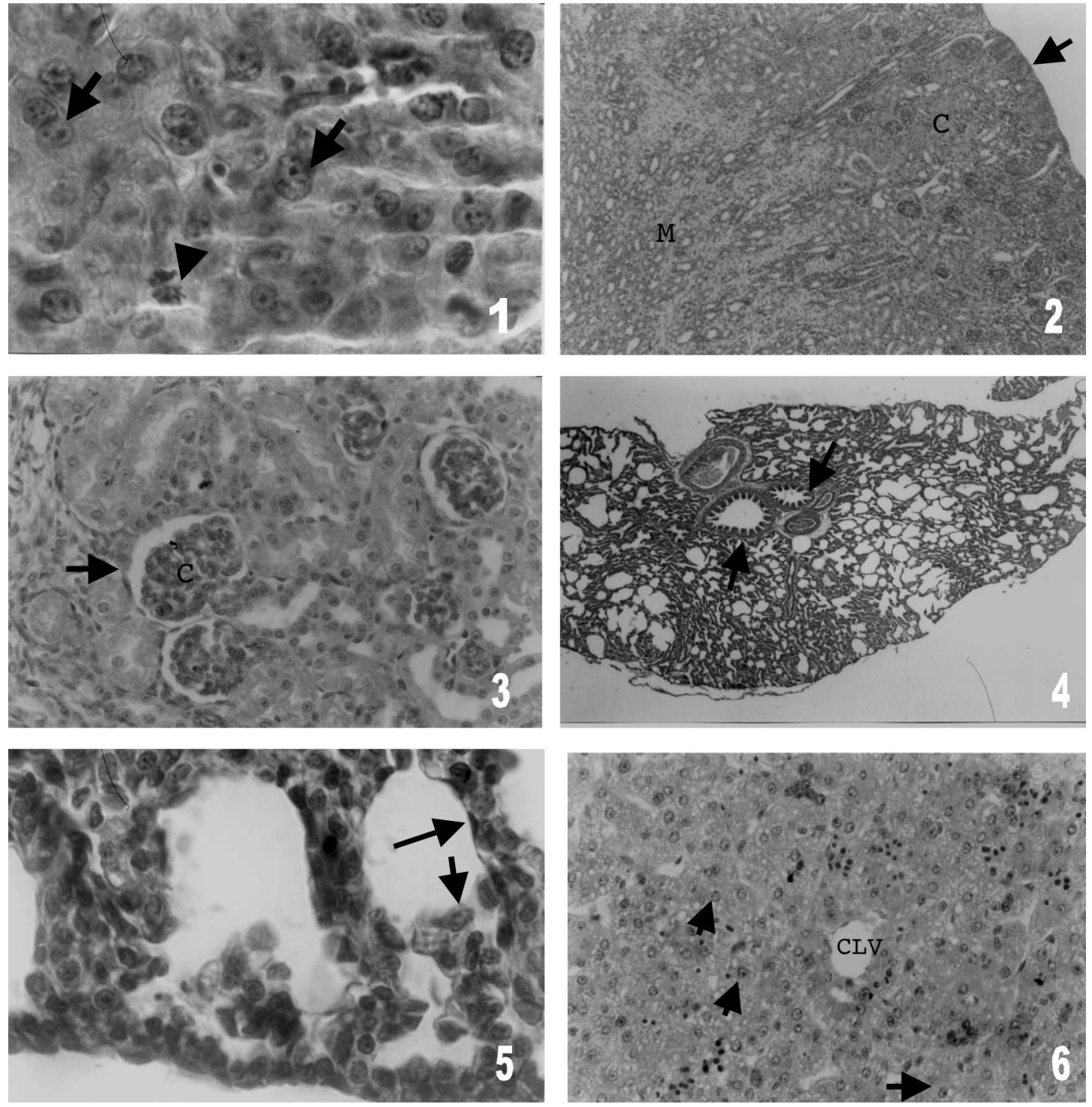

Fig. 1. Mitotic activity in trophoblasts (top of the arrow) and some cytotrophoblasts (arrow) in rat from Group III H-E. 428X. Fig. 2. Neonate kidney from Group I. Capsule (arrow), cortical regions (C) and medullar (M). H-E. 42X.

Fig 3.Renal glomerulus in rat from Group III constituted by a bunch of capillary (C), Bowman capsule (arrow) and capsular space (*). H-E. 428X.

Fig. 4. Neonate lung from Group II. Alveolus with varied diameters (*) and bronchioli (arrows). H-E. 42X.

Fig. 5. Pneumocytes type I (arrow) and type II (shorter arrow). H-E. 1071X.

Fig. 6. Center-lobular vein (CLV) and hepatocytes (arrows). H-E. 428X. 
with dexamethasone for 10 days didn't alter the morphology of the kidneys, liver and lungs of the neonates. It was verified in the kidneys, renal capsule well preserved, cortical region with numerous developed renal glomerulus, proximal and distal tubuli, and in the medullar region the presence of collecting tubuli (Figs. 2 and 3). In the lungs it was observed well developed bronchioli, covered by epithelial simple cubic tissue, alveoli with varied diameters and covered by pneumocytes type I and II, dense interalveolar septa and alveolar cells from the dust in the light (Figs. 4 and 5). In the liver it were evidenced the center-lobular veins, well preserved hepatocytes and arranged in strings around the center-lobular vein (Fig. 6).

\section{DISCUSSION}

According to the results, the treatment with dexamethasone did not affect the implantation neither the histology of the sites of implantation, but there was a reduction in the number of sites in group IV, due to the mortality of the animals. These results are accordingly to
Nevagi \& Kaliwal (2001) that emphasize that a dosage of dexamethasone does not affect the implantation, having effect only in a more advanced stage of gestation. Regarded to the reduction in group IV, it was probably because of the prolonged treatment with dexamethasone, as according to Pedesen \& Obyrne, this may be related to the toxic effects of the drug, where the prolonged use of glucocorticoids, especially when administered through systemic via is limited by important adverse effects. These include adrenal suppression, bones, conjunctive tissue and, in children, a decrease in the speed of growth.

The histological analysis of the kidneys, liver and lungs of the neonates did not show any change in the tissue of the organs treated with dexamethasone, because the changes in the organogenesis were only evidenced when the dexamethasone was administered during gestation and even so with high dosage (Ortiz et al., 2001; Cleasby et al., 2003; Seckl, 2004). Thus, we conclude that the treatment with dexamethasone for 10 days in rats does not affect the fertility and the development of the lungs, liver and kidneys of the neonates, while the administration for 15 days leads to a high maternal mortality.

MORAES, E. F.; WANDERLEY-TEIXEIRA, V. ; TEIXEIRA, A. A. C.; SILVA, W. E.; BATISTA, A. P. C. \& LEMOS, A. J. J. M. Efecto del tratamiento con dexametasona, por 10 y 15 días, sobre la fertilidad en ratas inducidas a ovarios poliquísticos por la iluminación constante. Int. J. Morphol., 26(3):659-663, 2008.

RESUMEN: El estudio tuvo el objetivo de obtener informaciones sobre la fertilidad en ratas tratadas con dexametasona por 10 y 15 días seguidos, para ovarios poliquísticos, inducidos por iluminación constante. Se utilizó 40 ratas albinas (Rattus norvegicus albinus) con 90 días de edad, del linaje Wistar, las cuales fueron divididas, en cuatro grupos, cada uno constituido por 10 animales: Grupo I - ratas mantenidas en ciclo claro/oscuro de 12/12 horas, y después de 100 días sometidas a la evaluación de la fertilidad (control); Grupo II- ratas mantenidas bajo iluminación constante, durante 100 días, y luego sometidas a la evaluación de la fertilidad ; Grupo III - ratas mantenidas bajo iluminación constante, a lo largo de 100 días, y posteriormente tratadas con dexametasona por diez días, y sometidas a la evolución de la fertilidad; Grupo IV - ratas mantenidas bajo iluminación constante, durante 100 días, en seguida tratadas con dexametasona por 15 días, y sometidas a la evaluación de la fertilidad. Los resultados mostraron que el número de sitios implantados fue 38(GI), 37(G2), 32(G3), y 06(G4). La reducción en el grupo IV fue como consecuencia de la alta mortalidad durante la experiencia, probablemente en función del largo tratamiento con dexametasona. Esos sitios presentaron aspectos histológicos semejantes. El análisis macroscópico de los neonatos no mostró ningún vestigio de malformación. Tampoco fueron observados abortos. El tratamiento con dexametasona por 10 días en ratas, no afecta la fertilidad y el desarrollo de los pulmones, hígado y riñones de neonatos, mientras que la administración por 15 días lleva a una alta mortalidad materna.

PALABRAS CLAVE: Fertilidad; Ovarios poliquísticos; Dexametasona; Ratas.

\section{REFERENCES}

Aihara, M.; Kobayashi, H.; Kimura, T.; Hayashi, S. \& Kato, J. Changes in uterine estrogen receptor concentration in persistent estrus and persistent diestrous rats. Endocrinology Japanese, 35(1):57-70, 1988.

Bensosn, B. \& Orts, R. J. Regulation of ovarian growth by the pineal gland. In: Regulation of organ and tissue growth. Gross R. J. ed. New York, Academic Press, 1972.

Bigsby, R. M. \& Young, P. C. Progesterone and dexamethasone inhibition of uterine epithelial cell proliferation: studies with antiprogesterone compounds in the neonatal mouse. J. Steroid Biochem. Mol. Biol., 46(2):253-7, 1993. 
MORAES, E. F.; WANDERLEY-TEIXEIRA, V.; TEIXEIRA, A. A. C.; SILVA, W. E.; BATISTA, A. P. C. \& LEMOS, A. J. J. M. Effect of the treatment with dexamethasone, for 10 and 15 days, on the fertility in induced rats to polycystic ovaries, by constant illumination. Int. J. Morphol., 26(3):659-663, 2008.

Buckle, J. W. Animal Hormone. London, Edward Arnold, 1983. pp. 20-36.

Caldas, D. \& Schrank, Y. Síndrome de Cushing por uso abusivo de descongestionante nasal contendo dexametasona: Relato de caso. Rev. Bras. Otorrinolaringol., 67(6): 86871, 2001.

Canlon, B.; Erichsen, S.; Nemlander, E.; Chen, M.; Hossain, A.; Celsi, G. \& Ceccatelli, S. Alterations in the intrauterine environment by glucocorticoids modifies the developmental programme of the auditory system. Eur. J. Neurosci., 17(10):2035-41, 2003.

Cleasby, M. E.; Livingstone, D. E.; Nyirenda, M. J.; Seckl, J. R. \& Walker, B. R. Is programming of glucocorticoid receptor expression by prenatal dexamethasone in the rat secondary to metabolic derangement in adulthood. Eur. J. Endocrinol., 148(1):129-38, 2003.

Cruz, F. C. M.; Smaniotto, S. \& Simões, M. J. Morphological aspects of the cervical mucosaof persistent estrous rats under action of estrogen and/or dexamethasone. Braz. J. Morphol. Sci., 13(1):100, 1996.

Fritz, M. A. \& Speroff, L. The endocrinology of the mentrual cycle: the interaction of folliculogenesis and neurendocrine mechanisms. Fertil. Steril., (38):509-29, 1982.

Huang, T. J. \& Shirley, L. I. P. Dexamethasone inhibits luteinizing hormone-induced synthesis of steroidogenic acute regulatory protein in cultured rat preovulatory follicles. Biol. Reprod., 64(1):163-70, 2001.

Melo, M. A. B.; Geber, S.; Sabino, S. M.\& Sampaio, M. Clinical treatment and assisted reproduction in infertility associated to polycystic ovaries. Reprod. Clim., 35(2):827, 2000.

Nevagi, S. A. \& Kaliwal, B. B. Effect of dexamethasone on implantation and pregnancy in albino rats. Indian J. Exp. Biol., 39(11):1163-5, 2001.

Neves, W. S. Cronobiologia e suas aplicações na prática médica. 7(1):2000. Available in: <http://www.famerp.br/ publicacoes/revistahb/Vol7-N1/5-cronobiologia. html>. access in: 15/12/2005.

Ortiz, L. A.; Quan, A.; Weinberg, A. \& Baum, M. Effect of prenatal dexamethasone on rat renal development. Kidney Int., 59(9):1663-9, 2001.
Pardi, P. C. Aspectos morfológicos do endométrio de ratas albinas em estro permanente. Tese de Mestrado - Escola Paulista de Medicina, São Paulo, 1992.

Patriarca, M. T. Efeitos do tamoxifeno no endométrio de ratas em estro permanente. Tese de Mestrado - Escola Paulista de Medicina, São Paulo, 1995.

Pedesen, S. \& Obyrne, P. A. Comparision of the efficacy and safety of inhaled corticosteroids in asthma. Allergy, 39:1-34, 1997

Prata Lima, M. F.; Soares, Jr. J. M.; Reis, J. C.; Salum, R. \& Baracat, E. C. Desenvolvimento de policistose ovariana em ratas pinealectomizadas. Reprodução e Climatério, 10(2):73-5, 1995.

Santos, J. M.; Smaniotto, S.; Evêncio-Neto, J. \& Simões, M. J. Aspectos morfológicos do endométrio de ratas submetidas à iluminação constante (estro permanente). Arquivos do Instituto Biológico, 62:47, 1995.

Scavo, L. M.; Newman, V.; Ertsey, R.; Chapin, C. J. \& Kitterman, J. A. Maternally administered dexamethasone transiently increases apoptosis in lungs of fetal rats. Exp. Lung Res., 29(4):211-26, 2003.

Seckl, J. R. Prenatal glucocorticoids and long-term programming. Eur. J. Endocrinol., 151(3):49-62, 2004.

Stewart, P. J.; Zaloudek., C. J.; Murphy Inman, M. \& Webster, R. A. Effects of dexamethasone and indomethacin on estrogen-induced uterine growth. Life of Science, 33:2349-56, 1983.

Terán-Dávila, J. \& Teppa-Garrán, A. D. Polycystic ovary syndrome of extra-ovarian origin. Invest. Clin., 42(1):5178, 2001.

Wrenn, T. R.; Wood, J. R. \& Bitman, J. Oestrogen responses of rats neonatally sterilized with steroids. J. Endocrinol., 45:415-20, 1969.

Correspondence to:

Profa. Dra. Valéria Wanderley Teixeira.

Universidade Federal Rural de Pernambuco.

Departamento de Morfologia e Fisiologia Animal.

Área de Histologia

Rua Dom Manoel de Medeiros s/n - Dois Irmãos

CEP: 52.171-900

Recife-PE - BRAZIL

Email: valeria@dmfa.ufrpe.br

Recibido : 05-01-2008 Aceptado: 29-07-2008 
